\title{
Environmentally friendly determination of urinary trans, trans-muconic acid for biological monitoring of benzene exposure by green high-performance liquid chromatography
}

\author{
Dong-Hyug Yang, Mi-Young Lee ${ }^{1, \star}$ and Yong Lim Won ${ }^{1}$ \\ Institute for Molecules-based New Drug Development, Chung-Ang University, Seoul 156-756, Korea \\ ${ }^{1}$ Korea Occupational Safety and Health Agency, Occupational Safety and Health Research Institute, Incheon 403-711, Korea \\ (Received Ocrober 18, 2012; Revised November 14, 2012; Accepted November 14, 2012)
}

\section{소변 중 뮤콘산의 친환경 HPLC 분석방법을 이용한 벤젠 노출 생물학적 노출평가 \\ 양동혁• 이미영 ${ }^{1, \star • ~ ㅇ ㅝ ㄴ ㅇ ㅛ ㅇ ㄹ ㅣ ㅁ ~}{ }^{1}$ \\ 중앙대학교 분자조절신약개발연구소, ${ }^{1}$ 한국산업안전보건공단 산업안전보건연구원 (2012. 10. 18. 접수, 2012. 11. 14. 수정, 2012. 11. 14. 승인)}

\begin{abstract}
An environmentally friendly, so-called green, high performance liquid chromatography method was developed and validated for the determination of trans, trans-muconic acid (t,t-MA) in human urine as a biomarker of benzene exposure. After urinary t,t-MA was extracted and enriched using solid-phase extraction, a MF-Ph1 SG80 $(150 \mathrm{~mm} \times 2.0 \mathrm{~mm}$ I.D., $5 \mu \mathrm{m})$ column with a mobile phase of $10 \mathrm{mM} \mathrm{KH_{2 }} \mathrm{PO}_{4}$ containing $0.1 \% \mathrm{H}_{3} \mathrm{PO}_{4}$ was used for isocratic separation of t,t-MA with UV detection at $259 \mathrm{~nm}$. The calibration curve was constructed in the range of $0.1-5.0 \mathrm{mg} / \mathrm{L}$ with good linearity $\left(\mathrm{r}^{2}=0.9992\right)$. The intra-day and inter-day precision (as RSD) were $0.9-8.5 \%$ and $3.1-4.5 \%$, respectively. The average recovery ranged from $97.5 \%$ to $101.7 \%$. The green sample preparation and separation with no organic solvents were successfully achieved. The validated method would be suitable for the routine biological monitoring of benzene exposure in the occupational settings.

요 약: 벤젠 노출의 생물학적 노출인 인체 소변 중 뮤콘산(trans, trans-muconic acid) 분석을 위한 녹색 HPLC (Highr performance liquid chromatography) 분석방법을 개발하고 검증하였다. 이온교환수지 고상추 출 카트리지를 사용하여 소변 중 뮤콘산을 추출하고, MF-Ph1 SG80 (150 mm × $2.0 \mathrm{~mm}$ I.D., $5 \mu \mathrm{m})$ 칼럼 과 이동상 $\left(10 \mathrm{mM} \mathrm{KH} \mathrm{KHO}_{4}+0.1 \% \mathrm{H}_{3} \mathrm{PO}_{4}\right)$ 을 뮤콘산의 $\mathrm{HPLC}$ 분석에 사용하였으며 검출은 자외가시부검 출기 $259 \mathrm{~nm}$ 에서 실시하였다. 0.1-5.0 mg/L 범위에서 상관계수 $\left(\mathrm{r}^{2}\right) 0.9992$ 이상의 양호한 직선성을 나타 내는 검량선을 얻었다. 일내 및 일간 정밀성(RSD)은 각각 $0.9-8.5 \%$ 및 3.1-4.5\%였으며, 평균 회수율은 97.5-101.7\% 범위였다. 본 연구에서는 유기 용매를 전혀 사용하지 않지만 기존 방법과 동일한 분석 성능 을 가지고 있는 친환경 분석법을 개발하였다. 확립된 분석법은 벤젠 노출 평가를 위한 근로자의 생물학 적 모니터링 방법으로 활용될 수 있을 것이다.
\end{abstract}

Key words: green high performance liquid chromatography, trans, trans-muconic acid, benzene, biological monitoring, HPLC-UV

\ Corresponding author

Phone : +82-(0)32-510-0825 Fax : +82-(0)32-518-0862

E-mail : cookmom@kosha.net 


\section{Introduction}

Benzene is a volatile industrial chemical widely used as an organic solvent and in the synthesis of other chemicals. ${ }^{1}$ Various industries use benzene to produce other chemicals, such as rubbers, lubricants, dyes, detergents, drugs and pesticides. Benzene is also present in exhausts from automobile engines, as well as cigarette smoke and smoke from other combustion processes. $^{2}$ Therefore, benzene exists in air worldwide with ppb level in environmental settings or up to ppm level in some workplaces. Occupational exposures mainly occur within the petrochemical industry or in manufacturing industries that require aromatic solvents or glues which contain benzene such as rubber production, shoe manufacturing and printing. ${ }^{3}$ The chronic exposure of human to low level of benzene in workplaces has been associated with the possible development of severe diseases such as leukemia. ${ }^{4}$ The International Agency for Research on Cancer (IARC) classified benzene as a Group 1 carcinogen (carcinogenic to humans). ${ }^{5}$ Accordingly, benzene has been under control of regulatory authorities to ensure reduced occupational exposures and improvement of workers' health. So, monitoring benzene exposure is essential for protecting the individuals who are exposed occupationally to this toxicant.

As shown in Fig. 1, benzene is primarily metabolized in the liver to a series of ring-hydroxylated and

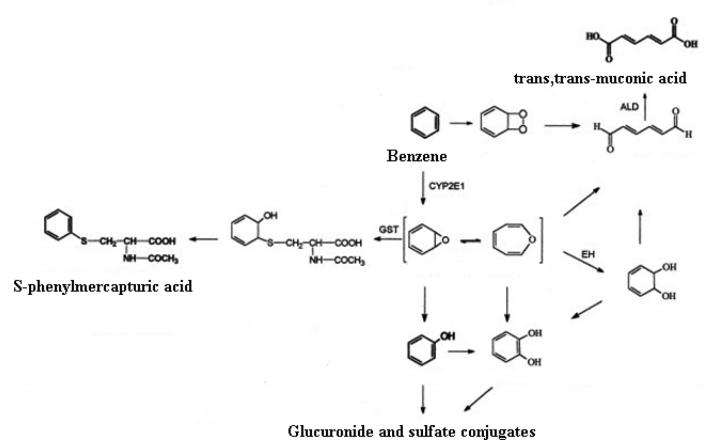

Fig. 1. Metabolic pathways of benzene. Abbreviations: CYP2E1, cytochrome P450 2E1; GST, glutathione$S$-transferase; EH, epoxide hydrolase. conjugated metabolites as well as ring-opened products, which are excreted in urine. ${ }^{6-8}$ Biological monitoring of these metabolites has been considered as a useful method to evaluate the chemical exposure in the human body. Benzene exposure at the workplace can be monitored by determination of benzene or benzene metabolites in biological samples such as blood, exhaled air and urine. Biological monitoring is useful tool for the assessment of the human health risks from chemical exposure, particularly for cancer. Determination of un-metabolized benzene in blood is diagnostically more specific than measurement of urinary metabolites. However, since the sampling of urine is much simpler, the determination of urinary metabolites has become widely applied. Two minor metabolites of benzene, namely trans, trans-muconic acid (t,t-MA) and $S$-phenylmercapturic acid (S-PMA), have been proposed as good indicators of benzene exposure for benzene exposure. ${ }^{9}$ They have been recommended as biological indicators for occupational exposure by the American Conference of Governmental Industrial Hygienists (ACGIH), with biological exposure indices (BEIs), respectively, of $500 \mu \mathrm{g} / \mathrm{g}$ creatinine for t,t-MA and $25 \mu \mathrm{g} / \mathrm{g}$ creatinine for SPMA in end-shift urine. ${ }^{10}$ The concentration of SPMA in urine represents diagnostically more sensitive parameter. However, from the analytical point of view, the quantitative determination of t,t-MA is more practical, as it can be carried out by HPLC-UV, in contrast to the GC/MS or HPLC-MS/MS analysis of S-PMA, not suitable for the routine analysis in industrial laboratories. ${ }^{11}$ Thus, the biological monitoring of t,t-MA has been widely used as a valid tool for the practice of occupational safety and health, as well as regarded as a suitable biomarker for exposure to benzene down to level of 1 ppm. ${ }^{12}$ In comparison to other benzene metabolites, urinary t,t-MA has advantages in terms of simplicity, applicability and robustness of analysis at occupational exposure settings. Thus, urinary t,t-MA has been widely used for occupational biological monitoring of benzene exposure at the workplace. The Korea occupational safety and health agency (KOSHA) has proposed BEI of $1000 \mu \mathrm{g} / \mathrm{g}$ creatinine for t,t-MA to regulate 
exposure to benzene in the workplaces. ${ }^{13}$

Recently, many efforts to apply green analytical methods have been increasing and many methodologies have been proposed in order to replace toxic reagents and polluting solvents, to minimize consumption of energy, reagents and samples, and to avoid waste generation. ${ }^{14}$ For the development and validation of chromatographic methods, the optimization of some critical analytical parameters including accuracy, sensitivity, reproducibility, simplicity, cost effectiveness, flexibility and speed is generally required. However, other aspects concerning environmental impact of analytical methods are not commonly considered. The application of green chromatographic methods is desirable from the viewpoint of the environment, human health and the economy in order to replace reagents and solvents with less toxic or non-toxic materials for the measurement and smaller amount of toxic waste after measurement. ${ }^{15}$

The aim of this study was to develop a simple, rapid and green (environmentally friendly) HPLC method for evaluating the level of t,t-MA in human urine excreted by workers occupationally exposed to benzene. The developed solid phase extraction (SPE) and HPLC separation method with no organic solvents used was validated and successfully applied for routine quantification of t,t-MA in the urine of workers occupationally exposed to benzene. In this study, we demonstrated that HPLC method could meet the requirements of green chemistry with regard to the reduction of the use of solvents and other reagents by increasing the speed of analysis and downsizing the SPE procedure.

\section{Experimental}

\subsection{Chemicals and materials}

t,t-MA (98\%) was purchased from Aldrich (St Louis, MO, USA). Glacial acetic acid (99.7\%), potassium dihydrogen phosphate $\left(\mathrm{KH}_{2} \mathrm{PO}_{4}\right)$ and phosphoric acid (85\%) were obtained from Sigma (St Louis, MO, USA). Water was deionized and filtered through a Simplicity water purification system (Millipore S.A., Molsheim, France) before use. All other chemicals were of analytical grade commercially available. Solid phase extraction (SPE) of urine was carried out using a Varian (Lake Forest, CA, USA) Bond ElutSAX (100 mg, $1 \mathrm{~mL}$ ) cartridge.

\subsection{Instrumentation and HPLC conditions}

HPLC analysis was performed using a Shiseido HPLC system (Nanospace, Shiseido, Tokyo, Japan) consisting of SI-1/2001 pump, an automatic six-port switching valve (SI-2012), an autosampler (SI-1/ 2003) coupled to the degasser (SI-1/2009) and UVVis detector (S1-1/2002). A Capcell Pak MF Ph-1 SG80 (150 mm $\times 2.0 \mathrm{~mm}$ I.D., $5 \mu \mathrm{m}$, Shiseido) was employed for the separation. The mobile phase was $10 \mathrm{mM} \mathrm{KH}_{2} \mathrm{PO}_{4}$ containing $0.1 \% \mathrm{H}_{3} \mathrm{PO}_{4}$. The flow rate was set at $0.20 \mathrm{~mL} / \mathrm{min}$. The samples were kept in the autosampler at $4{ }^{\circ} \mathrm{C}$ prior to injection. Column temperature was maintained constant at $40{ }^{\circ} \mathrm{C}$ using thermostatically controlled column oven (SI-1/2004) and the injection volume was $10 \mu \mathrm{L}$. The isocratic elution was held for $9 \mathrm{~min}$ (total run time $9 \mathrm{~min}$ ) and UV detection was performed at $259 \mathrm{~nm}$. Instrument control and data acquisition were carried out using S-Microchrom (Shiseido) SMC21 software (version number: 5,0,1,257).

2.3. Preparation of standard solutions and quality control samples

Ten milligrams of t,t-MA standard was accurately weighed into a $100 \mathrm{~mL}$ brown volumetric flask, dissolved with water to $100 \mathrm{~mL}$. This stock solution was serially diluted with pooled human urine from non-smoker male volunteers to provide calibration standard samples with the concentrations as follows: $0.1,0.2,0.5,1.0,2.0,3.0,5.0 \mu \mathrm{g} / \mathrm{mL}$. Calibration samples were extracted by SPE and analyzed by HPLC-UV method as described above. A quality control (QC) samples were prepared separately following the same procedure in the preparation of t,t-MA standard solutions. QC samples, which were used in both the method validation and during the biological monitoring, were prepared by spiking the standard working solutions into pooled human urine, giving the t,t-MA concentrations of 0.5 (low), 1.0 
(medium) and 2.0 (high) $\mu \mathrm{g} / \mathrm{mL}$ of t,t-MA in urine. QC samples were stored at $5{ }^{\circ} \mathrm{C}$ and brought to room temperature before use.

\subsection{Sample preparation}

The Bond Elut SAX cartridges containing $100 \mathrm{mg}$ of strong basic anion-exchange material was conditioned and equilibrated with $1 \mathrm{~mL}$ of water. After applying $500 \mu \mathrm{L}$ of urine mixed with $300 \mu \mathrm{L}$ of phosphate buffer $(\mathrm{pH}=7.4)$, the cartridges were washed with 1 $\mathrm{mL}$ of $0.1 \%$ aqueous acetic acid. t,t-MA was finally eluted with $2 \mathrm{~mL}$ of $10 \%$ aqueous acetic acid. An aliquot $(10 \mu \mathrm{L})$ of eluate was directly injected into the HPLC system for the determination of t,t-MA.

\subsection{Validation procedures}

For method validation purpose, spot urine samples were collected from healthy non-smoker male subjects not occupationally exposed to any organic solvents. However, it is practically impossible to acquire real blank urine samples, because benzene is ubiquitous pollutant in the environment. Due to the unavailability of a blank urine matrix, a pooled urine lot collected from non-smoker male volunteers was used to assess the performance of HPLC method developed. The method performance parameters including selectivity, linearity, limit of detection (LOD), limit of quantification (LOQ) and recovery have been characterized.

The selectivity was investigated by comparing chromatograms of six different samples from six volunteers, and both un-spiked and spiked urine were analzed with the result over the LOQ level. Calibration curves were constructed by assaying t,tMA standard urine samples at seven concentrations in the range of $0.1-5.0 \mu \mathrm{g} / \mathrm{mL}$ with least square linear regression. The LOD and LOQ of the method were assessed by six replicates of the analysis of the t,t-MA spiked urine samples. The precision of the entire method was assessed at three levels of QC samples and expressed as the relative standard deviation (RSD). QC samples were analyzed in six replicates on the same day (intra-day precision) and on three different days (inter-day precision). Total recovery was calculated as the relative content between measured and nominal concentration of the QC samples. The total recovery of t,t-MA was determined by comparing the peak areas obtained from the pooled blank urine sample spiked with the t,t-MA before SPE extraction procedure. This procedure was repeated for six replicates at three concentration levels of $0.5,1.0$ and $2.0 \mu \mathrm{g} / \mathrm{mL}$.

\section{Results and discussion}

\subsection{Sample preparation}

Either liquid-liquid extraction (LLE) or SPE has been employed for sample pretreatment of t,t-MA in urine. Currently, SPE with an ion-exchange resin has been used more frequently, due to its easier handling combined with high reproducibility and recovery for the enrichment of t,t-MA as well as the robustness of the technique. Therefore, the previously reported SPE procedure recommended by $\mathrm{WHO}^{16}$ was downsized to reduce the sample size of urine and the amount of chemicals required to apply the green parameter, as shown in Fig. 2. Moreover, $300 \mu \mathrm{L}$ of phosphate buffer $(\mathrm{pH}=7.4)$ was mixed with urine samples prior to SPE procedure, since many authors reported that more reproducible recovery rates were found when urine samples were adjusted to $\mathrm{pH}$ 7-10 prior to application on SAX columns. ${ }^{12}$ SPE recovery was calculated by comparing the area responses of extracted and non-extracted standard solutions in

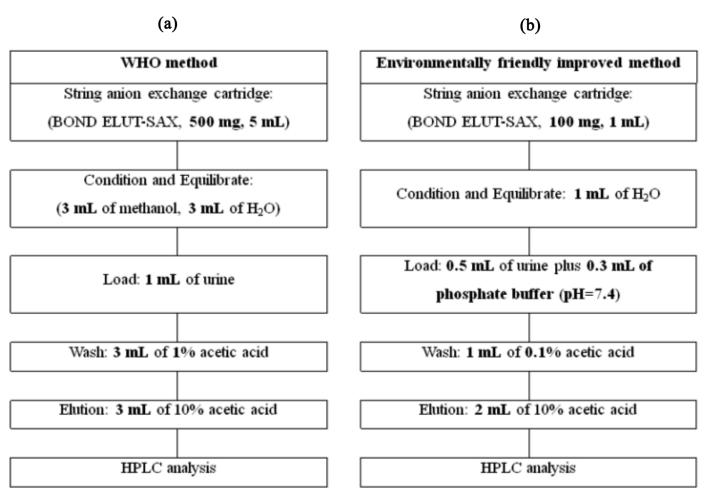

Fig. 2. Comparison of SPE sample preparation procedures between (A) WHO and (B) environmentally friendly improved method. 
Table 1. SPE recovery for t,t-MA in water $(n=6)$

\begin{tabular}{cc}
\hline \hline Spiked level of t,t-MA $(\mu \mathrm{g} / \mathrm{mL})$ & SPE recovery $(\%)$ \\
\hline 0.1 & 90.3 \\
0.5 & 104.0 \\
1.0 & 108.3 \\
3.0 & 101.9 \\
5.0 & 99.8 \\
\hline
\end{tabular}

water containing t,t-MA at various concentrations. As shown in Table 1, the mean values of SPE recovery $(n=6)$ ranged from $90.3 \%$ to $108.3 \%$. Even though organic solvent such as methanol was not used for conditioning the SPE cartridge, which was considered as the important step for optimization of the extraction efficiency, the recovery was satisfactory enough for practical application of this method.

\subsection{HPLC method development}

Analytical HPLC is generally performed using a stationary-phase column of $4.6 \mathrm{~mm}$ internal diameter (I.D.) and $25 \mathrm{~cm}$ length at a mobile-phase flow rate of about 1-1.5 mL/min. Under these conditions, each operating HPLC instrument generates over $1 \mathrm{~L}$ of effluent a day that is disposed of as chemical waste. ${ }^{17}$ The purchase of new instruments such as ultra high performance liquid chromatography (UHPLC) system is not always essential for implementing greener analytical HPLC in the laboratory. In this study, solvent saving and waste reduction were simply achieved by both changing column internal diameter from $4.6 \mathrm{~mm}$ to $2.0 \mathrm{~mm}$ I.D. and the elevation of column temperature $\left(40{ }^{\circ} \mathrm{C}\right)$, thereby leading to more rapid separation at a flow rate of $0.2 \mathrm{~mL} / \mathrm{min}$. Since the use of water as a mobile phase in the HPLC is a cheap, safe and environmentally friendly alternative to organic solvents typically used, aqueous separation of t,t-MA from urine matrix was achieved on a phenyl column with no organic solvent. Under these chromatographic conditions, t,t-MA was eluted at about $3.8 \mathrm{~min}$ and almost completely separated from matrix components by isocratic elution.

The main advantages offered by developed green method is short extraction time, reduction in the amount of sample required, high sample throughput, reduced cost, and improved safety since it does not require the use of organic solvent. Table 2 shows comparison of HPLC conditions between $\mathrm{WHO}^{16}$ and environmentally friendly improved method. Liquid chromatography is one of the biggest consumers of organic solvents in analytical chemistry. Therefore, green chromatographic method could start with reducing the use of organic solvents and replacement with environmentally benign ones.

\subsection{Method validation}

Due to the complexity of biological fluids and the high inter-subject variability of urine in particular, assessment of matrix effects in different urines has been included as part of the validation procedure. As shown in Fig. 3(A), no significant interference from endogenous substances was observed at the retention times of t,t-MA. Fig. 3(B) also shows the representative chromatogram of pooled human urine spiked with t,t-MA. Good selectivity for the analyte was shown by symmetrical resolution of the peaks, with no significant chromatographic interference nearby the

Table 2. Comparison of HPLC conditions between (A) WHO and (B) environmentally friendly improved method

\begin{tabular}{|c|c|c|}
\hline Parameters & WHO method & Environmentally friendly improved method \\
\hline Column & $\begin{array}{l}\text { MOS Hypersil C8, Shandon Scientific, Ltd. } \\
(200 \mathrm{~mm} \times 4.6 \mathrm{~mm} \mathrm{ID}, 5 \mu \mathrm{m})\end{array}$ & $\begin{array}{l}\text { Capcell Pak MF Ph-1 SG80, Shiseido fine chemicals. } \\
(150 \mathrm{~mm} \times 2.0 \mathrm{~mm} \text { ID }, 5 \mu \mathrm{m})\end{array}$ \\
\hline Column temperature & Ambient & $40{ }^{\circ} \mathrm{C}$ \\
\hline Flow rate & $1 \mathrm{~mL} / \mathrm{min}$ & $0.2 \mathrm{~mL} / \mathrm{min}$ \\
\hline Mobile phase & $\begin{array}{l}\text { Methanol containing } 0.1 \% \text { phosphoric acid, } \\
\text { isocratic }\end{array}$ & $10 \mathrm{mM} \mathrm{KH}_{2} \mathrm{PO}_{4}$ containing $0.1 \% \mathrm{H}_{3} \mathrm{PO}_{4}$, isocratic \\
\hline Injection volume & $10 \mu \mathrm{L}$ & $10 \mu \mathrm{L}$ \\
\hline Retention for t,t-MA & Not reported & $3.7 \mathrm{~min}$ \\
\hline Detection & $\mathrm{UV}$ at $259 \mathrm{~nm}$ & $\mathrm{UV}$ at $259 \mathrm{~nm}$ \\
\hline
\end{tabular}




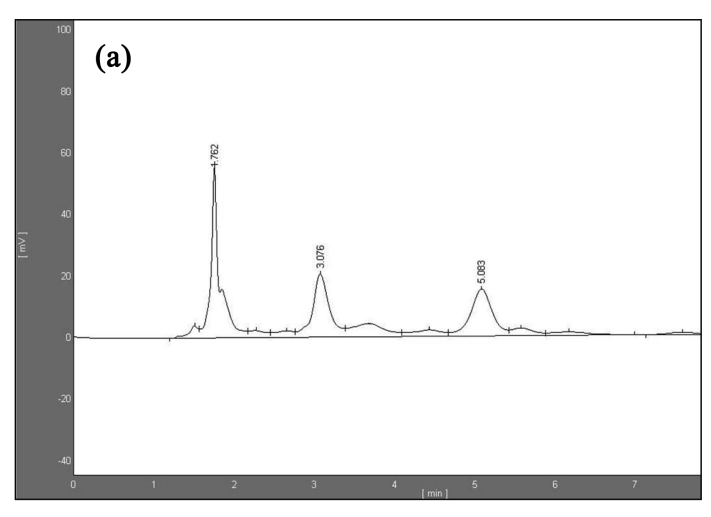

(b)
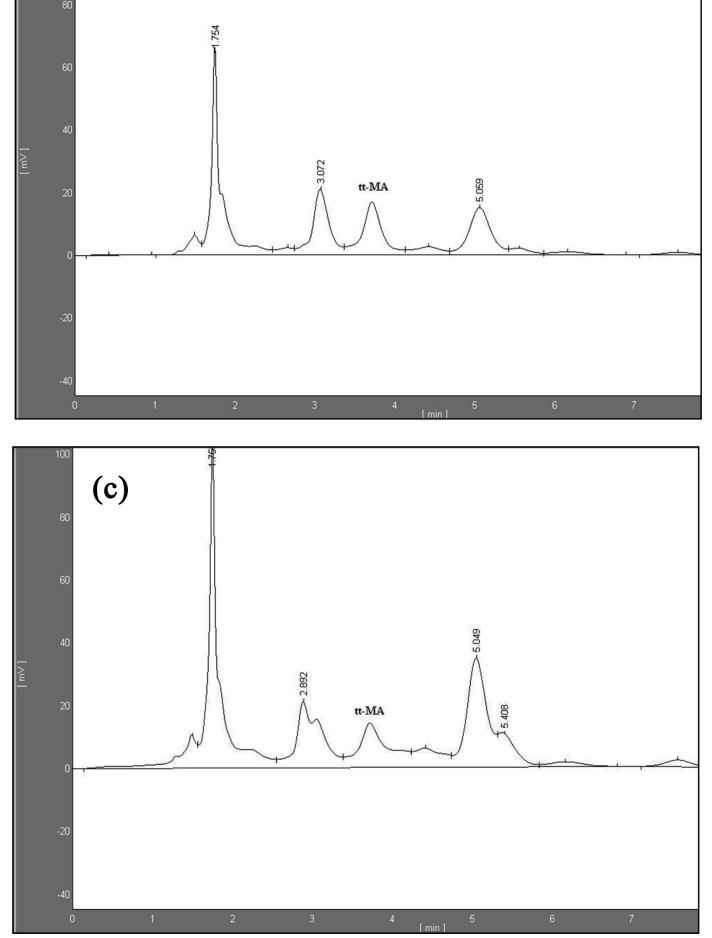

Fig. 3. HPLC chromatograms of (A) pooled human urine, (B) t,t-MA spiked urine containing $2.0 \mu \mathrm{g} / \mathrm{mL}$ of $\mathrm{tt}-$ $\mathrm{MA}$ and (C) occupationally benzene-exposed worker's urinary sample containing $1.5 \mu \mathrm{g} / \mathrm{mL}$ of t,t-MA. retention time of the analyte in the human urine samples. Typical retention time for t,t-MA was about $3.8 \mathrm{~min}$ and the total run time was $9 \mathrm{~min}$.

The data of linearity, LOD and LOQ were summarized in Table 3. The calibration curve was constructed by subtracting the background level peak area from the values determined for the spiked urines. The result showed that the calibration curve was linear over the concentration range of 0.1-5.0 $\mu \mathrm{g} / \mathrm{mL}$. The linear regression equation for the analyte was $y=70535 x+132281$, where $y$ was the concentration of the analyte and $\mathrm{x}$ was the peak area of the analyte. The correlation coefficient $\left(\mathrm{r}^{2}\right)$ was more than 0.9992. The LOD in pooled urine matrix for t,t-MA was $0.05 \mu \mathrm{g} / \mathrm{mL}$ at $\mathrm{S} / \mathrm{N}$ ratio of 3 . Due to the unavailability of a human urine sample completely free of t,t-MA, this LOD presented could be utilized only to estimate non-detectable amounts of t,t-MA in urine samples. An estimated LOQ value for t,t-MA in urine was calculated to be $0.1 \mu \mathrm{g} / \mathrm{mL}$.

The intra-day and inter-day RSDs at three QC levels were not more than $8.5 \%$ and $4.5 \%$, respectively, indicating an acceptable precision of the present method (Table 3). The average total recoveries of $\mathrm{t}, \mathrm{t}-$ MA from human urine following SPE at three QC levels were $97.5 \%, 95.2 \%$ and $101.7 \%$, respectively. The precision and total recovery were satisfactory and met the generally accepted criteria for bioanalytical method validation with a RSD of $15 \%$ and a relative error within $\pm 15 \%$. $^{18}$

\subsection{Method application}

A simple down-sized sample preparation followed by a high-performance liquid chromatography under "organic solvent-free", i.e., aqueous, conditions for the quantification of a benzene metabolite, t,t-MA, in

Table 3. LOD, LOQ, precision and total recovery for t,t-MA in pooled human urine $(\mathrm{n}=6)$

\begin{tabular}{|c|c|c|c|c|c|c|c|}
\hline \multirow{2}{*}{$\begin{array}{c}\text { LOD } \\
(\mu \mathrm{g} / \mathrm{mL})\end{array}$} & \multirow{2}{*}{$\begin{array}{c}\mathrm{LOQ} \\
(\mu \mathrm{g} / \mathrm{mL})\end{array}$} & \multirow{2}{*}{$\begin{array}{c}\text { Nominal concentration } \\
\text { of } \mathrm{t}, \mathrm{t}-\mathrm{MA}(\mu \mathrm{g} / \mathrm{mL})\end{array}$} & \multirow{2}{*}{$\begin{array}{l}\text { Relative to } \\
\text { BEI }^{\mathrm{a}}\end{array}$} & \multicolumn{2}{|c|}{ Precision (RSD, \%) } & \multicolumn{2}{|c|}{ Total recovery $(\%)$} \\
\hline & & & & Intra-day & Inter-day & Mean (\%) & Range (\%) \\
\hline \multirow{3}{*}{0.05} & \multirow{3}{*}{0.1} & 0.5 & $1 / 2 \times \operatorname{BEI}\left(\mathrm{Q}_{\text {low }}\right)$ & 8.5 & 3.1 & 97.5 & $88.4-103.8$ \\
\hline & & 1.0 & BEI $\left(Q_{\text {medium }}\right)$ & 3.6 & 3.4 & 95.2 & $90.8-101.5$ \\
\hline & & 2.0 & $2 \times \operatorname{BEI}\left(\mathrm{Q}_{\text {medium }}\right)$ & 0.9 & 4.5 & 101.7 & $100.7-103.2$ \\
\hline
\end{tabular}

${ }^{\mathrm{a}} \mathrm{BEI}$ : biological exposure index. BEI of t,t-MA recommended by KOSHA is $1.0 \mu \mathrm{g} / \mathrm{mL}$. 
human urine was applied to measure the urinary levels of 30 subjects, consisting of both 15 occupationally benzene-exposed workers and 15 nonoccupationally individuals. The urinary concentration of t,t-MA for occupationally exposed workers was not more than $1.5 \mu \mathrm{g} / \mathrm{mL}$ while that of nonoccupationally individuals was less than $0.7 \mu \mathrm{g} / \mathrm{mL}$. Representative chromatogram of pooled occupationally benzene-exposed worker's urine is presented in Fig. 3(C). The primary purpose for biological monitoring is the prevention of adverse effects on the monitored worker. A detection of target analyte is not a direct indicator of an adverse health effect in the monitored worker, but it may be used as a biomarker of a potential health effect. Therefore, biological data is necessary to interpret the relationship between occupational exposure and t,t-MA as a biomarker for the assessment of exposure to benzene. The developed green method would be suitable for the routine biological monitoring of occupational exposure to benzene in the field laboratories.

\section{Conclusion}

A green HPLC method combined with the downsized solid-phase extraction procedure for the quantification of t,t-MA in human urine was developed using conventional HPLC system. With no organic solvents, the developed method enabled to quantify urinary $t, t-$ MA with good precision and accuracy. The short run time of $9 \mathrm{~min}$ also would provide high sample throughput, thus making the method suitable for the routine biological monitoring of occupational exposure to benzene in the occupational medicine. The use of green analytical methods would be a smart strategy to provide both environmental and economic benefits.

\section{References}

1. Agency for Toxic Substances and Disease Registry (ATSDR), Toxicological profile for Benzene, http:// www.atsdr.cdc.gov/toxprofiles/tp. asp?id=40\&tid=14, Assessed 27 Jun 2011.

2. M. Carrieri, E. Bonglio, M. L. Scapellato, I. Macc, P.
Faranda, E. Paci, G. B. Bartolucci and G. Tranfo, Toxicol. Lett., 192, 22-28 (2010).

3. C. P. Weisel, Chem. Biol. Interact., 184, 58-66 (2010).

4. M. Arayasiri, C. Mahidol, P. Navasumrit, H. Autrup and M. Ruchirawat, Sci. Total Environ., 408, 4855-4862 (2010).

5. International Agency for Research on Cancer (IARC), http://www.iarc.fr, Assessed 27 Jun 2011.

6. P. J. Sabourin, W. E. Bechtold and R. F. Henderson, Anal. Biochem., 170, 316- 327 (1988).

7. G. Witz, Z. Zhang and B. D. Goldstein, Environ. Health Perspect., 104, 1195-1199 (1996).

8. S. M. Rappaport, S. Kim, Q. Lan, G. Li, R. Vermeulen, S. Waidyanatha, L. Zhang, S. Yin, M. T. Smith and N. Rothmane, Chem. Biol. Interact., 184, 189-195 (2010).

9. P. Manini, G. De Palma, R. Andreoli, P. Mozzoni, D. Poli, M. Goldoni, M. Petyx, P. Apostoli and A. Mutti, Toxicol. Lett., 193, 229-235 (2010).

10. L.-C. Lin, Y.-M. Chiung, J.-F. Shih, T.-S. Shih and P.-C. Liao, Anal. Chim. Acta, 555, 34-40 (2006).

11. Deutsche Forschungsgemeinschaft (DFG), 'Essential Biomonitoring Methods', Wiley-VCH, Weinheim, 2006.

12. G. Scherer, T. Renner and M. Meger, J. Chromatogr. B, 717, 179-199 (1998).

13. Korea occupational safety and health agency (KOSHA), http://oshri.kosha.or.kr, Assessed 27 Jun 2011.

14. S. Armenta, S. Garrigues and M. de la Guardia, Trends Anal. Chem., 27, 497-511 (2008).

15. M. Farre, S. Perez, C. Goncalves, M. F. Alpendurada and D. Barcelo, Trends Anal. Chem., 29, 1347-1362 (2010).

16. World Health Organization (WHO), Biological Monitoring of Chemical Exposure in the Workplace Guidelines: Volume 2, http://whqlibdoc.who.int/hq/1996/WHO_ HPR_OCH_96.2.pdf, Assessed 27 Jun 2011.

17. C. J. Welch, N. Wu, M. Biba, R. Hartman, T. Brkovic, X. Gong, R. Helmy, W. Schafer, J. Cuff, Z. Pirzada and L. Zhou, Trends Anal. Chem., 29, 667-680 (2010).

18. U.S. Food and Drug Administration, Guidance for Industry: Bioanalytical Method Validation, http://www. fda.gov/downloads/Drugs/Guidance Compliance Regulatory Information/Guidances/ucm070107.pdf, Assessed 27 Jun 2011. 